\title{
China's Africa expansionism: Competitive questions
}

\author{
Marié-Luce Muller \\ Managing Director and CI Analyst \\ IBIS Business and Information Services \\ mlm@ibis.co.za \\ www.ibis.co.za
}

\section{Introduction}

Since the beginning the 2000s, China's foreign policy thinking on Africa became a priority. Africa has not received attention from China to this extent since the 1970s (Davies, Endinger, Tay and Naidu 2008.) This strategic shift in international relations between China and Africa is attracting a great deal of interest and commentary. China's investment push in the continent has been facilitated by generous aid and loan packages. China has cancelled US $\$ 1,4$ billion of African debt and announced additional debt relief of more than US $\$ 1,3$ billion. At a summit of African leaders in Beijing in 2007, China said it would also double its level of assistance to Africa by 2009 (Davies et al. 2008.)

Driven by its growing needs for energy and raw materials to power its booming economy over the last five years, China has poured millions of dollars of investment in various African countries. At the end of 2006, Chinese investments in Africa reached US\$11,7 billion and spanned the range of manufacturing, trade, transportation and agriculture. Two-way trade soared to US\$55 billion in 2006, four times the 2000 level. Chinese leaders say they want to increase trade volumes to US $\$ 100$ billion dollars by 2020 . China is soon to become one of the continent's largest foreign-direct investment (FDI) sources. Some companies like telecommunications giant Huawei feature prominently on the African map and are taking growing stakes in African markets, selling anything from air-conditioners to electrical bicycles. China said it would also double its level of assistance to Africa by 2009 (All Africa.com 2007; Jacoby 2007; Xinhuanet 2006).

According to in-depth and recognized research by the Centre for Chinese Studies at Stellenbosch University (CCS), China's new foray into Africa is attracting international attention and contentious debate (Davies et al. 2008). China is seemingly engaging Africa on new terms that are not shaped by traditional powers. It represents a new approach to the continent that the authors have termed China's 'coalition engagements' in Africa. China's foreign aid forms an integral component of this paradigm (Davies and Endinger 2008).

\section{China's foreign policy focus}

Chinese foreign policy towards Africa at the turn of the century underwent a dramatic shift according to the CCS. As 'China Inc.' started to internationalize after 1998, Africa became a strategic focus for Chinese outward-bound companies. Africa became more important to China and it established the Forum for China-Africa Cooperation (FOCAC) housed within the Ministry of Foreign Affairs. FOCAC's mission is to coordinate Chinese foreign policy objectives toward Africa (Forum for China-Africa Cooperation 2008). Through FOCAC, China's Ministries of Foreign Affairs and Commerce have aligned their respective responsibilities toward more effective coordination and implementation of a Chinese foreign and aid policy towards Africa. 
China has a broad and, at times, vague definition of foreign aid. The monitoring of its aid commitments and their implementation is proving difficult, even for the Ministry of Commerce, as well as government think-tanks. China's approach has been one of mutual respect (Davies et al. 2008). Although it also awards small African countries aid and investment support, it is likely that resource-rich countries such as Angola, Sudan, Nigeria and Zambia and politically strategic countries, such as South Africa, Ethiopia and Egypt, are priority countries in China's broader African engagement.

Figures on China's aid disbursements to Africa remain vague. In the absence of a central aid agency, the lack of general time series data on aid flows and the non-transparent nature of Chinese loans complicate the process of defining, calculating and monitoring China's development assistance to the continent. The Chinese government delivers bilateral aid in terms of grants, interest-free loans and concessional loans and the aid policy formulation process for these is outlined and discussed in this report. China EXIM Bank, one of China's three policy banks and the sole provider of concessional financing, had financed over 300 projects in Africa by mid-2007, constituting almost $40 \%$ of its loan book. The Bank's lending practices are often linked to China's foreign aid policy providing concessional loans mostly to infrastructure development. The recent MOU between China EXIM Bank and the World Bank holds out the promise of donor collaboration between both institutions in African infrastructure programmes.

The Chinese Government has repeatedly expressed a desire for resource-backed financing agreements in Africa modelled on its relations with Luanda, increasingly known as the 'Angola Model'. An emerging trend is that of China's rolling out concessional loans in Africa, of which China EXIM Bank is the sole lender. Essentially, the debtor country, represented by its finance minister will negotiate a minimum RMB 20 million (US\$2,4 million) loan (Naidu and Mbazima 2008.) The loan interest rate and grace period are separately negotiated, with, in the case of Angola, repayment due on the 21st of March and the 21st of September of each year following loan negotiation. Loans are given for infrastructure, social or industrial projects. The loans are a foreign policy tool, particularly in Africa's cash-strapped but resource-rich countries, especially those with major infrastructure needs and those who can use their proven resources as collateral. The financing arrangement also addresses China's domestic challenge of structural unemployment. According to the China EXIM Bank's concessional loan requirements, Chinese contractors must be awarded the infrastructure contract financed by the loan.

\section{Strategic trade zones}

Part of China's strategic industrial plan towards Africa is to establish five preferential trade and industrial zones for Chinese business entry in Africa. Located in Zambia, Mauritius, Egypt, Nigeria and, possibly, Tanzania, this initiative emanated from the Beijing Action Plan announced at FOCAC 2006. A financing and infrastructure component of these zones will be categorized as foreign aid by the Ministry of Commerce at the next FOCAC summit to be held in late 2009 in Cairo.

\section{Public relations challenge}

It has, however, not been plain sailing for China. Stung by criticism that it was out to exploit Africa, China mounted a public relations (PR) offensive at the 2007 World Economic Forum (WEF) Africa summit (June, Cape Town) (Business Report 2007). Chinese business and political heavyweights took centre stage. Li Ruogu, president of the Export-Import Bank of China, was one of four co-chairs and Li Zhaoxing, China's foreign minister until recently, was a panelist.

African leaders have expressed concerns that Chinese investment in the continent was simply replicating European colonialism. The Chinese have realized that their biggest challenges in 
Africa are not the usual suspects of corruption and weak capital markets but public relations. Some African leaders welcome European investment, but when the Chinese invest, they are skeptical. China's public relations drive is more about coming out of the closet and engaging than it is about packaging sound bites that African audiences want to hear and the PR offensive is set to continue (Business Time 2007).

\section{Implementing China's Africa policy}

In combining economic assistance, debt relief and expanding market access for African states, China's African engagement strategy is similar to that of the West. China is unique, however, because it significantly relies on the active involvement and cooperation of Chinese corporations in its approach to the continent (Davies and Endinger 2007). The profusion of Chinese corporations involved in Africa is part of China's 'go out' (zou ququ) policy, which is designed to develop these corporations' technological skills, exploit China's comparative advantages, gain access to key inputs, open new markets abroad, create global Chinese brands and help China to avoid becoming overly dependent on export-led development (Bates and Reilly 2007; Davies et al. 2008). More than 7000 Chinese enterprises have invested in 160 countries and regions around the world, with a total outward foreign investment stock and flow estimated at US\$50 billion and US\$5 billion, respectively, by 2005.

The Chinese government promotes business ties with Africa by providing information, coordination mechanisms and financial assistance for Chinese companies and investors in Africa. For example, Chinese construction firms operating in Africa receive export credit for feasibility studies, government guarantees for bank loans, export credits for financing the operational cost of projects and lines of credit for capital goods and machinery (Chen, Chiu, Orr and Goldstein 2007.) Such government support was listed by Chinese firms as the second most-important factor, following the pursuit of new markets, in their decision to invest in Africa.

In 2000, the first FOCAC founded the China-Africa Joint Business Council, provided government support for investment by Chinese enterprises in African countries and established an array of economic partnerships. At the 2006 FOCAC, China pledged US\$3 billion in preferential loans and US\$2 billion in export credits to African states over the next three years, created a special fund of US\$5 billion to encourage Chinese investment in Africa and established the China-Africa Joint Chamber of Commerce (Davies et al. 2008; Forum on China-Africa Cooperation 2006).

China also set up 10 centres for investment and trade promotion in sub-Saharan Africa. These centers provide business consultation services, special funds and simplified approval procedures for Chinese enterprises seeking to invest in Africa (Campbell 2007). In November 2004, China established the China-Africa Business Council (CABC) jointly with the UN Development Program in order to support China's private-sector investment in subSaharan Africa (CABC 2008). The CABC, a public-private partnership, replicates aspects of China's poverty alleviation-focused Guangcai Program, which encouraged investment and philanthropic links between coastal and inland regions of China.

In 2002 the government began selecting some 50 'national champions' from the most promising or strategic state-owned enterprises (SOEs) in China (Huang 2005). These large corporations enjoy a range of benefits from the government, including information-sharing networks, domestic tax breaks, cheap land, and low-interest funding from state-owned banks (The Times 2007). China's more dynamic and more profitable small and medium enterprises have also been expanding beyond China's borders. In total, more than 700 Chinese companies are involved in cooperative projects in Africa. Most of these firms are affiliates of state-owned enterprises in China, particularly in the capital-intensive resource extraction 
(such as oil and minerals) and construction sectors (Davies and Endinger 2008).

\section{Competitiveness issues and opportunities for South African business}

In terms of competing with Chinese companies, there is a realization that certain areas of competition would be counter productive, for example competing on cost. South African companies just do not have the benefit of low-cost labour enjoyed by their Chinese counterparts.

In an article published on the Polity Website in June 2006, it is said that business-to-business relations between Chinese and South African enterprises are now swiftly increasing in tempo (Polity.org 2006). The Beijing Axis (TBA) MD, Kobus van der Wath, said this tempo is increasing rapidly. 'Originally, companies on each side employed only an export model in dealing with the other country, using local agents. Now, while this model is still in use, a growing number of companies in both countries are moving towards direct business/business relationships. The Chinese sectors most interested in South Africa, and in Africa, in general, are the mining and related (such as heavy engineering, project engineering and mining equipment) industries. The Chinese telecommunications industry is interested in South Africa, the motor industries development programme is attracting the Chinese automotive industry, and Chinese electronics companies are interested in the South African and African markets, according to Van der Wath (Die Burger 2007; Polity.org 2006).

Competition against the Chinese should be on the basis of exploiting niche opportunities in especially the services sector. Some examples mentioned include mine safety equipment, information and communications technology, Sasol's gas-to-liquids technology and pebblebed modular reactor nuclear technology, and providing competitive intelligence (CI) and market intelligence services (Annual Bank Conference of Development Economics 2008).

China is here to stay and Chinese business also brings opportunity in the form of exports to China, forming strategic partnerships and entering into cooperation agreements. Van der Wath warns that South African companies that ignore competition from China and do not develop cooperation with them will lose in the end (TBA 2008).

\section{References}

All Africa. 2007. Available on the Internet at allafrica.com/stories. (Accessed 9 December 2008).

Annual Bank Conference of Development Economics (ABCDE) Centre for Chinese Studies Panel Discussion. 2008. China's role in financing Africa's development. Cape Town, June.

Bates, G. and Reilly, J. 2007. The tenuous hold of China Inc. in Africa. The Washington Quarterly 30(3):37-52.

Business Report, 2007. China charms the critics of its Africa business strategy, June.

CABC, 2008. Website information. Accessed 9 December 2008. Available at http://www.cabc.org.cn.

Campbell, K. 2007. 800 Chinese state-owned enterprises active in Africa, covering every country. Mining Weekly (September).

Chen, C., Chiu, P., Orr, R. and Goldstein, R. 2007. An empirical analysis of Chinese construction firms' entry into Africa. CRIOCM2007 International Symposium, Australia. 
Xinhuanet. 2006. Available at Web http://en.ce.cn/subject/CAF. (accessed 9 December 2008.

Davies, M. and Endinger, H. 2008. China increases its role in Africa's infrastructure developments. BusinessForum China (November).

Davies, M., Endinger, H., Tay, N. and Naidu, S. 2008. How China delivers development assistance to Africa. A research undertaking by the Centre for Chinese Studies, prepared for the Department for International Development (DFID), Beijing Centre for Chinese Studies, University of Stellenbosch.

Die Burger, 2007. Eetstokkies, energie en geld vir sake in China. (February).

Forum on China-Africa Cooperation, 2006. Beijing Action Plan (2007 - 2009).

Jacoby, U. 2007. Getting together: The new partnership between China and Africa for aid and trade. Finance and Development (a quarterly magazine of the IMF) 44(2).

Naidu, S. and Mbazima, D. 2008. China-African relations: A new impulse in a changing continental landscape. Elsevier. February.

Polity.org. 2006. Afro-Chinese business fusion. Available at http://www.polity.org.za.

The Beijing Axis, 2008. Publications available on www.thebeijingaxis.com.

The Times. 2008. China weighs up Wall Street. (September).

\section{About the author}

Marié-Luce Muller is a consulting CI analyst with IBIS Business and Information Services (Pty) Ltd, a leading Pretoria-based CI consultancy. She has a distinguished career in CI. Her primary experience lies in assisting companies in honing their CI capabilities. She also performs tracking and scanning activities on behalf of companies. Marié-Luce has published many articles on competitive intelligence (CEO Magazine, Finance Week, Business Week, Beeld, Die Burger and the South African Journal of Business Management), including an article on South Africa as an emerging CI player, which was published in an international publication of the Society of Competitive Intelligence Professionals (SCIP). She has also published a series of booklets on CI (Nuts and Bolts business series, published by Knowledge Resources) and is a member of a research team participating in an international study of CI practices among exporting companies. Previously, she was involved in research into the status of CI practices in South Africa. A member of SCIP, she holds a postgraduate degree from the University of Stellenbosch.

ISSN 1560-683X

Published by InterWord Communications for Department of Information and Knowledge Management, University of Johannesburg 